\title{
Bishop Mitsumyo Tottori: Patriotism Through Buddhism During World War II
}

\author{
KELLI Y. NAKAMURA
}

\section{INTRODUCTION}

In THE DOMINANT historical narrative about Japanese Americans in both Hawai'i and the mainland, it has been generally understood that leaders within the Japanese community, including Buddhist priests, were incarcerated for the duration of World War II. Authorities arrested 234 Issei priests from Hawai' $i$ and the mainland during the war as well as thirteen Nisei and Sansei priests. The majority of the priests were Nishi Hongwanji Buddhists, although authorities also arrested Sōtō Zen, Jōdo, and Shingon Buddhist priests. ${ }^{1}$ One exception was Mitsumyo Tottori of the Shingon Mission in Hawai 'i, who was never incarcerated even after Federal Bureau of Investigation (FBI) officials interrogated him. ${ }^{2}$ After his release, Tottori continued to conduct services for Nisei soldiers and represented an unusual exception to incarceration policies. While $5^{6}$ percent of his services were conducted for $\mathrm{O}$ 'ahu residents, the rest were for individuals living on the Neighbor Islands. The largest number of Neighbor Island services were for Maui residents followed by individuals from Hawai'i Island and Kaua'i. Tottori even held services for individuals living on Lāna'i

Kelli Y. Nakamura is an assistant professor of history at Kapi'olani Community College. Her research interests include Japanese and Japanese American history.

The Hawaiian Journal of History, vol. $5^{1}$ (2017) 
and Moloka'i, demonstrating his widespread impact throughout the Hawaiian Islands.

It would be erroneous to characterize Tottori as an example of Hawai'i's tolerant racial attitude in light of the wartime incarceration of more than 1,200 individuals, including many priests from the Islands. However, Tottori's experience reflected some of the curious inconsistencies in the extension of martial law policies. FBI officials noted his support of the Americanization of Nisei, which seemed to outweigh his country of origin or religious activities that justified the incarceration of other Buddhist priests. His actions during the war revealed the religious need that still existed within the Japanese community - a need that led families to request private services, despite wartime restrictions, and for Tottori to conduct services for unknown young men he read about in the newspapers. Conducting these services was particularly fraught with danger during a time when martial law represented the culmination of anti-Japanese and anti-Buddhist sentiment that had existed for years in Hawai' $i$. The experiences of Tottori further complicate the unique circumstances experienced by residents of Japanese ancestry in Hawai'i within the unprecedented implementation of martial law and selective incarceration policies.

\section{Arrival of Buddhism in the Islands and Fears OF "Alien" InFLuences 3}

Even before officials had formulated incarceration policies targeting dangerous influences or individuals within the Japanese community, such as Buddhist priests, Buddhism had been closely associated with Japanese immigrants. Japanese first brought Buddhism to the Islands as early as 1889. Shingon Buddhism arrived nearly 30 years after the arrival of other Buddhist sects, including the Hongwanji, Jōdo, Higashi Hongwanji, Nichren, and the Sōtō sect. ${ }^{4}$ As Japanese laborers became spiritually and psychologically disillusioned with the harsh conditions on the plantations, Buddhist teachings provided consolation and spiritual guidance for laborers and their families. The rise of Buddhism in a predominantly Christian environment was due, in part, to the deeper expression among Japanese immigrants of their need for a sense of community. Since the Gentleman's Agreement of 1907 had prohibited immigrants from leaving the plantation for work 
on the mainland, laborers were now economically tied to Hawai'i. According to scholar Dennis Ogawa, "with this loss of mobility came their growing need to normalize the community and to perpetuate cultural ties with the homeland." ${ }^{5}$ Buddhism restored cultural traditions, values, and beliefs that had been lost in the years of disruptive plantation labor. In 1902, the Reverend Yujiri Hōgen became the first Shingon Buddhist priest to arrive in Hawai'i. He established a small Daishi-dō in Lāhainā, Maui, which is the present-day Lāhainā Shingon Mission. Early devotees of Shingon Buddhism, who were often women, established many worship groups and by 1909 there were 115 such groups. ${ }^{6}$ By 1941 , there were 11 active Shingon temples found on O'ahu, Hawai'i Island, Kaua'i, and Maui, and a total of 114 Buddhist temples and shrines existed in Hawai ${ }^{6}$. ${ }^{7}$ According to information that Tottori provided when FBI officials arrested him, there were roughly 1,ooo families on O'ahu belonging to the Shingon sect along with 8 oo families on Hawai'i Island, 4 oo on Kaua'i, and 5 oo on Maui. ${ }^{8}$

Plantation owners also supported initial Buddhist missionary efforts by donating land and money to create a more stable and dependable plantation community and develop a strong ethnic identity among the Japanese to facilitate their strategy of "divide and rule" among different racial groups. They believed such missionaries fostered the sort of cultural differences that prevented worker solidarity and deepened ethnic divides. According to scholar Noriko Asato, "Buddhist priests and planters saw each other serving mutual interests. Buddhist priests initially stood on the side of the planters and reconciled troubles between Japanese workers and their plantation managers in exchange for planters' support for their ministries." ${ }^{9}$ Buddhism itself was also transformed within Hawai'i as part of its "Protestantization" or "Americanization" to make Buddhism more understandable to Nisei. ${ }^{10}$ Thus, temples were identified as "churches," priests were called "Reverends," Christian-type churches or pews were used in the temples, Sunday schools were created, and Buddhist gathas, or hymns, were translated into English and sung to Christian songs. Additionally, the Young Men's Buddhist Association (YMBA), which Buddhist officials created specifically to meet the needs of the Nisei, was patterned after the Young Men's Christian Association (YMCA).

Despite these Americanization efforts, by the 1920s, many whites alleged that the language schools were "under the control of reaction- 
ary Buddhist priests" who undermined the efforts of "genuine Americanization." 11 Thus, owing to their involvement in labor struggles and other perceived anti-American activities in the pre-war period, Japanese language schools became the target of territorial legislation designed to weaken their influence. They were considered "centers of an influence which if not distinctly anti-American, is certainly unAmerican." 12 During the 1920 strike, the largest labor conflict in the territory's history, the two leading newspapers, the Pacific Commercial Advertiser and the Honolulu Star Bulletin, repeatedly represented the strike as a racial conflict between loyal Americans and foreign Japanese. "The Japanese government," the Advertiser declared in an editorial, "is back of the strike; it is back of the organization of Japanese labor in the American Territory of Hawaii; it reaches out its arm and directs the energies and activities of its nationals here in these American islands just as it directs those at home."13 The Star Bulletin warned its readers that Japanese "priests, editors, and educators" sought to control the 25 , ooo Japanese plantation laborers in order to be the "masters of Hawaii's destiny." 14 Under the domination of these "alien agitators," Hawai'i would surely be "Japanized," whereby "Japanism would have become triumphant in Hawaii and wheels of the industries of this territory would have moved or halted at their behest." By the 1920s, the planters and the white press clearly saw the strike's "roots in the Japanese foreign language schools and the Japanese language press," and attacked this "alien" presence as detrimental to Hawai'i's future, particularly when bonds of solidarity might be established among the two largest ethnic groups on the plantations: the Japanese and the Filipinos. ${ }^{15}$

Subsequently, in the period leading up to World War II, the planters and military officials became increasingly suspicious of Japanese religions practiced in Hawai' $i$ and the mainland. A 1941 report, compiled by the Office of Naval Intelligence, depicted Japanese in the United States as an "inherently religious race" who "depend upon the authority, the ritual, and the doctrines of Shintoism or Buddhism, or both religions to act as moral factors to guide their personal conduct to aid their spiritual well being, both in life and hereafter." 16 The report further explained that the priests of both religions were held "in high regard" and "looked upon" as "leaders in the communities"; the "anti American and possibly subversive elements" it discovered in 
the Japanese communities were traced "almost invariably" to these priests. Their existence and influence within the ordinary Japanese immigrant community was a source of alarm:

Because of these priests, the nationalistic, Emperor-worshipping doctrines of Shintoism were kept alive among those Japanese whose tendencies were toward pro-Japanism and the fancied mission of the Yamato people. In the same way, certain priests and believers in Buddhism allowed the original meaning of their creed to become adulterated by the desire for Japanese expansion and the philosophy of Japanese supremacy over the other people of the earth. ${ }^{17}$

This fear by military officials contributed to their decision to incarcerate Buddhist and Shintō priests during World War II and close most shrines and temples. Almost overnight the Japanese community was deprived of its social, educational, and religious leaders, which created a void in leadership and aroused ambivalence and anxiety among the Japanese about their future in Hawai'i.

\section{Incarcerated Buddhist Priests}

On December 7 , while Japanese planes continued to fly over Pearl Harbor, the FBI and Army began their roundup of suspicious individuals. Priests, Japanese language teachers, and even fishermen were among the first to be picked up. Under the cover of darkness, and without any word of explanation to their families, military and government agents arrested Japanese men at their homes and took them to the Immigration Building in Honolulu for questioning.

In Hilo on the evening of December 7, a local policeman visited Myoshu Sasai, a Shingon Buddhist minister whom he knew from previous marital counseling sessions. Due to their personal relationship, the policeman did not enter the temple through the front entrance but instead went downstairs under the house and rapped on the floor for Sasai. When Sasai opened the door, the policeman said to him, "Sasai-sensei, please come with me." ${ }^{18}$ Before leaving, Sasai washed his face and informed his wife, who gave him \$20, a toothbrush, toothpaste, and a towel. Even before the December 7 attack, he intuitively felt he would be arrested in the event of war and had made "strong and long-lasting clothing-things that would not tear" in preparation 
of his arrest. ${ }^{19}$ That night, he slept in a small room in the back with his new clothes on a hanger nearby where he was visited by the police. According to Sasai, he was picked up in "one of Hilo's sampan buses which only 10 to 15 people could ride." ${ }^{20}$ This sampan bus made numerous stops picking up other Japanese before heading to Kìlauea Military Camp, where Sasai stayed for a number of months before military officials sent him to incarceration centers in the mainland. On the day of his departure from Hilo aboard the Waialeale to Honolulu, Sasai and other inmates realized that below them on another deck were Japanese volunteers from Hawai'i who were joining the U.S. army. Reflecting on this fact, Sasai noted the difference in their journeys and that for even other Japanese, his incarceration was expected due to his position as a Buddhist minister:

The father is on the top while the son is on the lower deck. Both are being taken [away], but their destinations are different ... Boys born in Hawaii, young boys from Hawaii are going. Even though their citizenship may be different, they are on their way. We are going someplace too. I thought that we were all being forced to go. "But, priest, you're going; so we'll go too.” Japanese are funny sometimes. My going was expected. That's when I realized that my going was to be expected. ${ }^{21}$

Sasai's observation of the community expectation of the incarceration of Buddhist priests during the war reflected the reality that many priests experienced. Authorities incarcerated more than 200 Japanese Buddhist priests from Hawai'i, who joined their mainland counterparts in War Relocation Authority (WRA) camps. Nippu Jiji newspaper editor Yasutaro Soga observed "close to a hundred Buddhists, Shinto, and Christian ministers, pastors, and lecturers" at Lordsburg, New Mexico, alone with 23 Buddhist ministers from Hawai'i and 31 from the mainland. The proliferation of Buddhist clergy inspired Soga to make a humorous observation about the benefits of having such a concentration of religious figures:

Whenever a funeral was held in the camp, if the deceased happened to be a Buddhist, dozens of clerics would line up at the service in colorful, beautifully decorated surplices. In the outside world one would never expect to see such an assemblage of ministers in such finery. Upon seeing this spectacle, someone joked, "if you have to die, now is the time."22 
Although Soga agreed with that statement, he was also very "disappointed" with the character of some of these priests, whom he felt "did not know the way of Buddha or God . . . since they knew too little about the world." According to Soga, "they secluded themselves in their sect or religion and did not know or care about anything beyond it," explaining their failure to enlighten others. With the closure of temples and shrines in both Hawai' $i$ and the mainland, incarceration had the desired effect of weakening the influence of Buddhism in America and Hawai'i. Yet in the Islands, Mitsumyo Tottori continued to practice and conduct services for the Japanese community, despite the closure of temples and the incarceration of religious figures elsewhere.

\section{Mitsumyo TotTori}

Mitsumyo Tottori was born on May 6, 1898, in Shikoku, Japan. By 1914 , Tottori had completed his final ordination ceremony and later graduated from the Shingon Shū Kyōtō University in 1924. He first went to the Hawaii Shingon Shū Betsuin in Honolulu, and in June 1927 became the resident priest at Komyoji Temple in Wailuku, Maui, where he met and married Aiko Fujitani of Lāhainā, Maui. Prior to the outbreak of war, Tottori, along with his wife, and nine children, had moved back to O'ahu, where he was the resident minister at Koshōji Temple in Hale“iwa. As a result of his affiliation with the Buddhist temples, authorities extensively investigated Tottori as well as newspaper editors, language school teachers, and other prominent members of the Japanese community. "Confidential Informant N" provided details on his education, travels to Japan, personal details such as the number of his children and their citizenship status. According to this informant, Tottori had written five or six articles that had appeared in the Hawaii Mikkyo, a monthly publication of the Shingon sect, to challenge the teachings of a wandering priest who came to Hawai'i in 1940 promoting the loyalty of the Japanese to Japan. The informant noted that Tottori "admitted that his articles caused some protest in the Japanese community, and that such articles would not be favorably received in Japan." Authorities were likely interested in Tottori, not just because of his position as a priest, but also that his ideas of promoting the Americanization of 


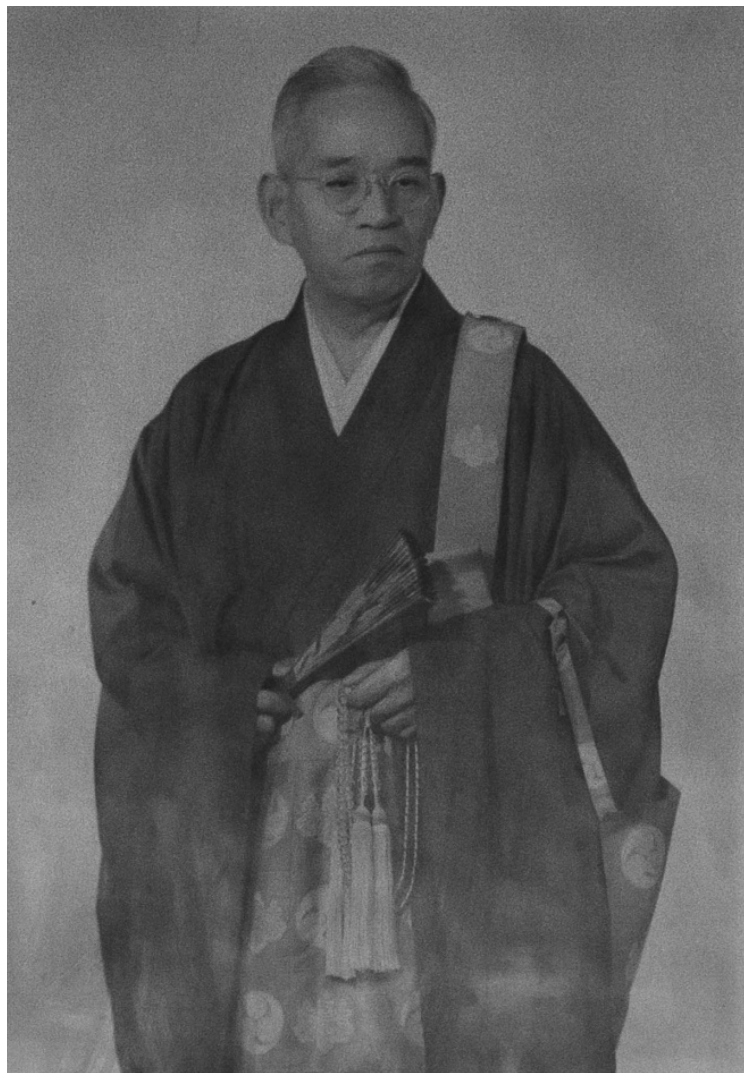

Photograph of Bishop Mitsumyo Tottori at Liliha Shingonji Mission. 2016. Courtesy of Kelli Y. Nakamura and Shirley S. Lam.

the Nisei were contrary to the opinion that officials had of the loyalty of the Issei.

Although Tottori's promotion of Americanization could be seen as at odds with his Buddhist faith, Tottori was not alone in celebrating American ideals of democracy through Buddhism. As early as 1918, the Reverend Yemyō Imamura of the Hongwanji Mission in Hawai' $i$ had written a number of articles and a short book on the promotion of democratic ideals through Buddhism. ${ }^{23}$ Arguing that Buddha's first sangha (congregation) was a model of democracy, 
Imamura believed that Buddha "formulated a certain set of moral precepts according to the spirit of universal brotherhood" that reflected democratic ideals. ${ }^{24}$ According to Imamura, Buddhist ideas were in "perfect harmony with the principles of democracy" and "whatever democracy there is in the East, it derives its power and support from Buddhism." ${ }^{25}$ While authorities were critical of the activism of Buddhist priests like Imamura in labor strikes, scholar Tsuyoshi Nakano argues that in the Americanization of Shin Buddhism, Issei clergy had incorporated the tenets of America's founding-freedom, equality, and human rights-and they demanded the improvement of workers' conditions based upon these principles. ${ }^{26}$ Buddhist priests like Imamura would not see any contradiction between their embrace of both Japanese and American ideas and their activism in local events. Both Imamura and Tottori thus embody what scholar Duncan Williams has called the "complex loyalties" of Issei priests prior to World War II as they straddled transnational identities and allegiances of both countries. ${ }^{27}$

More than two decades after Imamura promoted the Americanization of Japanese Buddhists, Tottori argued that "duty to this country, land of our adoption, came before duty to Japan, land of our birth" in an article appearing in the March 1940 issue of the Hawaii Mikkyo. ${ }^{28}$ According to Tottori's daughter, Kazuko, Tottori believed in loyalty to the United States as "he felt that his children were born in Hawai' $i$ and he owed it to the U.S. government that our children continue to be loyal to the U.S. government." ${ }^{29}$ Despite being a Japanese alien, Tottori developed close ties to Hawai'i with his wife, a Nisei from Maui. His first five children, who were born in the Islands, were American citizens. Thus, even when Tottori was reassigned to Japan from 1936 to 1940 , it appeared that he had every intention of returning to Hawai'i to practice his religion and to raise his growing family there. This intent was clearly evident when he registered the births of Tsunemichi and Takayo with the American Embassy in Japan.

All of Tottori's children attended American schools with the girls enrolled at McKinley High School, a Honolulu public high school that the majority of Nisei in Hawai'i attended in the 1920s and 1930s. As O'ahu's only public high school, it was often called "Tokyo High," and it was credited with Americanizing young Japanese Americans with a core curriculum that emphasized citizenship, leadership, and critical 
thinking. ${ }^{30}$ Tottori's four sons attended 'Iolani School, a private Episcopalian school in Honolulu that also emphasized education, moral citizenship, and American values. While Tottori wrote articles promoting Americanization and loyalty to the United States to other Nisei, he put these ideas in practice in the education of his children.

In the January $194^{1}$ issue of the Hawaii Mikkyo, Tottori further elaborated his ideas in an article entitled, "Destiny and the Role of the Yamato People in Hawaii." According to Tottori, "In the case of the second generation, Japan is their ancestral country . . . they feel that their loyalty should be shown to the United States. They live as they do because they are in the midst of the justice and freedom of America." Tottori believed that the Nisei were the "link" between Japan and America and "the hope for the true culture and development of the U.S.A." as they negotiated their bicultural identity with their American upbringing. ${ }^{31}$ In a June 1941 article entitled, "Recognition of Problems Confronting Fellow-Countrymen in America," which appeared in the Koyasan Jiho, a news pamphlet published by the head temple of the Shingon sect in Wakayama, Japan, he warned that "if there ever will be a conflict between the United States and Japan, always remember that the second generation will take up arms against you." In this article, Tottori took a much more militant, pro-American stance of the loyalty of the Nisei compared to Imamura, who was critical of war. Tottori's ideas also preceded the formal induction of Nisei troops in the armed forces by two years. Although the impact of these statements in Japan is unclear, American military officials paid close attention to them as tensions between the United States and Japan grew, and as authorities began to prepare for the arrest and incarceration of Japanese suspects with the outbreak of war.

On December 7, 1941, the Tottori family was preparing for daughter Sumiko's birthday at Hale 'iwa, where Tottori was the resident minister. Sumiko, who was celebrating her twelfth birthday, was in the temple attending a service conducted by her father when news broke that the Japanese had attacked Pearl Harbor. Recalling the events of the day, she remembered the disbelief and the fear of the congregation when people realized that the Japanese were attacking Hawai' $i$ :

And then suddenly I heard some kind of bombing or smoke coming off the airplane and the neighborhood and people in the membership 
[saying] "it's war, it's war." And I could still hear their fears, the feeling of it, it was there. I was in the temple with my father then and I still remember oh it's my birthday and here this is happening. ${ }^{32}$

Younger sister Sadako was away with another sibling doing errands when news broke of the Pearl Harbor attack. "I remember taking my sister to the store to buy a birthday present for her and the store manager said go home, because we've been bombed," she recalled. ${ }^{33}$ Soon after, FBI officials visited Tottori and took him away for interrogation. According to Sumiko, "I still remember FBI people coming and looking through his table and talking to my mother and then he was gone." ${ }^{44}$ Surprisingly, after a few days of interrogation with Tottori's wife praying every day, FBI officials released Tottori despite detaining the other priests they had apprehended. According to Tottori, "I don't know how the FBI got its information, but they had it. When I was led into the interrogation room, they showed me an article I had written and asked if it was mine. I think this is the reason why I was not interned." 55 Daughter Sadako also recalled that "my father did say when he came back . . . that when he was interrogated the FBI were very receptive of him, whatever he said and that when he left it was on very good terms . . . wasn't even hostile so my father was very satisfied." 36 Tottori's experience was exceptional as authorities had detained other Japanese Buddhist and Shintō priests with the outbreak of war and closed the temples. Tottori's nine children do not recall any fear or suspicion that surrounded their family, unlike the experiences of some who were ostracized by the community for fear of being considered similarly suspect. Nor do family members remember suspicions of collusion with authorities that precluded their father's incarceration, as there were collaborators within the Japanese community who informed on others for their own benefit.

Despite his initial arrest and likely the knowledge that authorities would be monitoring his actions to justify his incarceration, Tottori continued to conduct private services for Japanese families. As Sadako explains, "all the temples were closed ... so in other words he couldn't hold public services but he could conduct personal, private [services] at homes." As Jane Tottori explains, despite potential censure from authorities, Tottori continued to hold services due to the close relationship he had with many Nisei and their parents. 
It was more like word of mouth that he was the only one left and so ... it's small, the Japanese community is small . . most of the time he went to their homes because they couldn't come to the temple. They couldn't use any of the items that they had at the temple so he drove to these people's homes. I remember [mother] saying "oh we have to drive here." ${ }^{37}$

Sadako further elaborated on her father's motivations explaining, "I really felt that my father had a personal obligation to these young men because he had, in his articles, he was also encouraging them to join the military and fight for their country. And so as a priest I think that the $t \bar{o} b a$ [memorial tablets] that he created was his personal obligation and thank you to these men for fighting for this country." 38 For each memorial service, Tottori made a tōba for the Nisei who died during World War II. He also wrote down information on casualties in three small brocaded notebooks that he entitled Kinen Mei Bo ("the prayer book of names.") Each entry contained the first and last name of the individual, rank, age, and date of death. He also listed the hometown of the individual and included the name of the petitioner and their

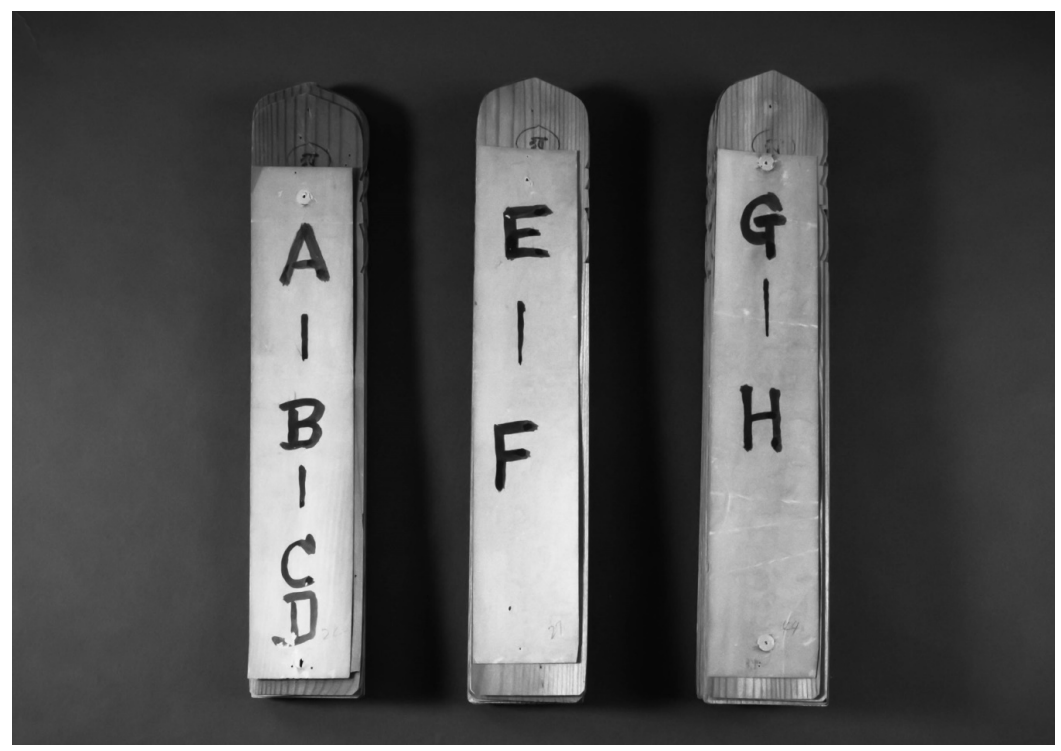

Tōba alphabetized by name. 2016. Courtesy of Kelli Y. Nakamura and Shirley S. Lam. 

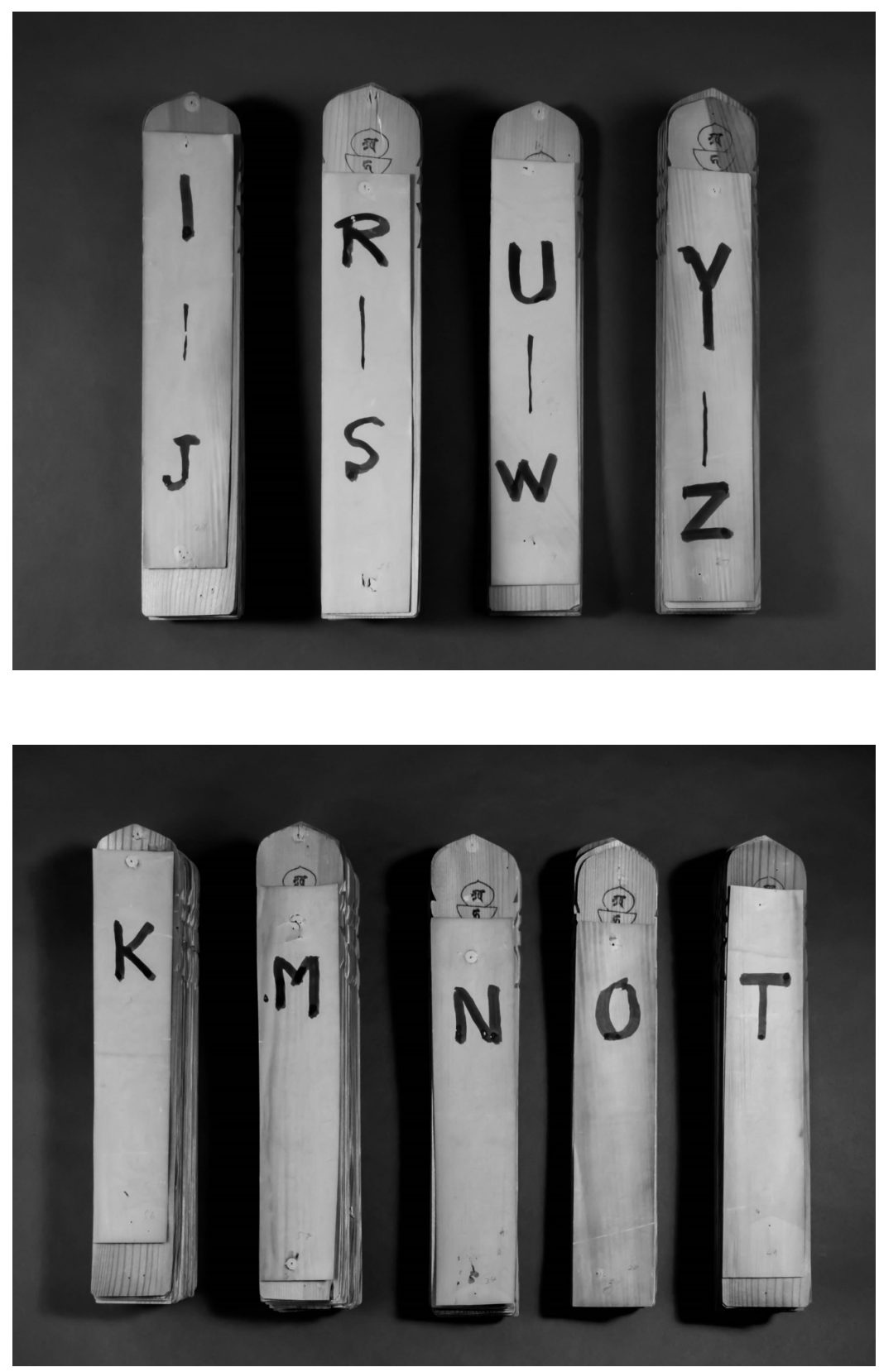

Tōba alphabetized by name. 2016. Courtesy of Kelli Y. Nakamura and Shirley S. Lam. 


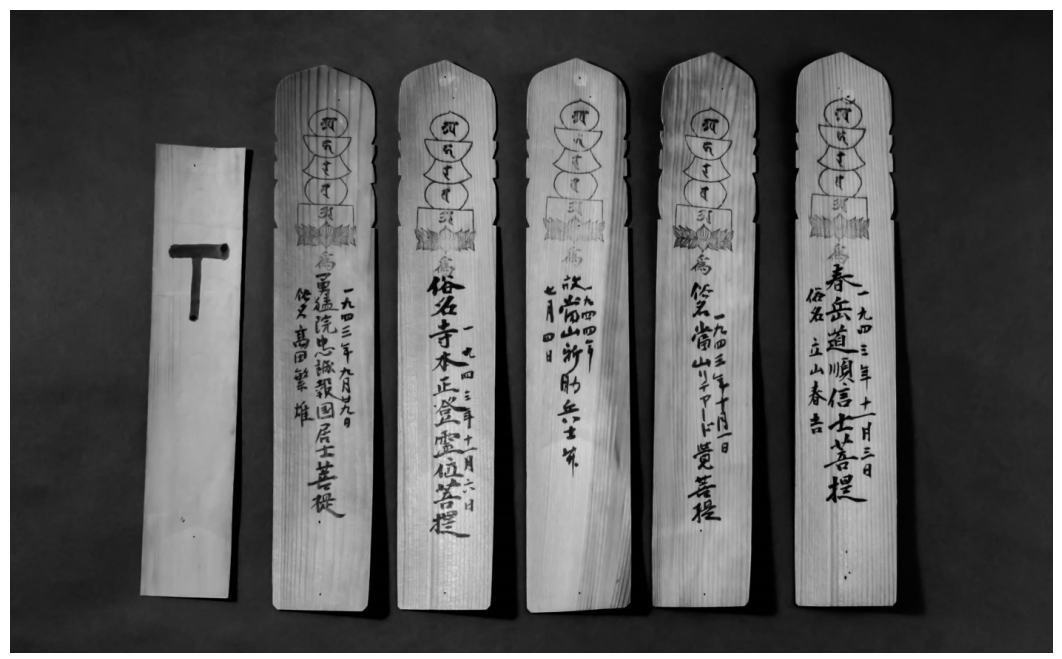

Tōba alphabetized by name. 2016. Courtesy of Kelli Y. Nakamura and Shirley S. Lam.

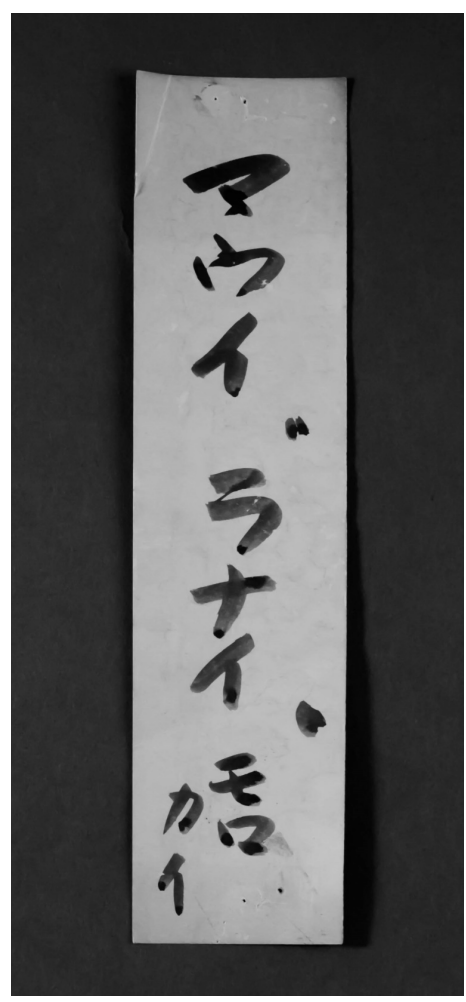

Tōba of residents from Maui, Lāna 'i, Moloka'i. 2016. Courtesy of Kelli Y. Nakamura and Shirley S. Lam. 
relationship to the deceased. Occasionally, Tottori also included the address or hometown of the petitioner as part of the information on these individuals. As daughter Kazuko explains, "My father was personally involved because he knew the parents of the sons that went to war and he was very devout and prayed for the safety of the sons." 39

As a Buddhist priest in Hawai' $i$ for more than 17 years by the time war broke out, Tottori was familiar with the local Japanese community, which was predominately Buddhist. By 1941, it was estimated that the Shintō shrines had about $5^{\mathrm{o}}$,ooo members and the Buddhist temples has "at least twice as many." ${ }^{40}$ The number of Buddhists in Hawai' $i$ was alarming to military officials and justified the removal of Buddhist priests. Yet it also created a religious need that existed in the community with the absence of religious figures and the entry of the Nisei in the armed forces. According to scholar Gwenfread Allen, of the 32,197 Hawai'i men inducted by Selective Service boards, 49.9 percent were of Japanese ancestry. ${ }^{41}$ Thus, more than 16 ,ooo Japanese men from the Islands went off to war, leaving behind their families who could only hope and pray for their return.

Subsequently, hundreds of petitioners sought out Tottori to conduct prayer and memorial services and, according to Tottori's family, the services that he provided to families became so widely known that even the Waialua plantation manager, John H. Midkiff, assisted Tottori in his spiritual duties. Kazuko recalls that "the manager of the plantation realized this was helping these families . . . and so they gave a special permit to get the extra gas." ${ }^{42}$ Midkiff was well-known within the Waialua and Hale "iwa community and familiar with the Japanese in the area. His allowance of extra gas rations testifies to the knowledge Midkiff had of Tottori's actions during the war and the religious need that existed within the Japanese community. Midkiff's actions were unusual during a period of censorship of Japanese cultural practices within the Japanese community and on the plantations. Hale'iwa's more rural location on O'ahu, which was dominated by plantation interests, could have enabled plantation officials to exert more discretionary control over their Japanese laborers. Midkiff did have a close relationship with his workers and the large Japanese community in the area, which was comprised of 3,680 individuals according to the 1940 census. ${ }^{43}$ After the war, Midkiff also wrote in support of the Issei encouraging their Nisei children to prove their loyalty to 
America, despite the fact that they themselves had been denied citizenship rights. Although he recognized that the Issei may be "torn between two emotions" of being born in Japan but raising their children in America, Midkiff encouraged the Issei to support the service of the Nisei to America. ${ }^{44}$ Perhaps this sentiment explains his support of Tottori's actions during the war.

In addition to serving the local Japanese communities on the North Shore of O'ahu, Tottori conducted services for others living in Central and East Honolulu in areas like Waipahu, Aiea, Nu'uanu, Kaimukī, and Mō'ili'ili. Many families and acquaintances from O’ahu requested these services, but nearly 44 percent of the services Tottori conducted were for servicemen from the other Islands. The largest number of Neighbor Island services were for Maui residents as the family had lived on Maui for a number of years before moving to Hale'iwa. Tottori's wife's family was also from Maui and close community ties likely remained.

In addition to conducting services for members of the Shingon sect both on and outside of $\mathrm{O}^{\prime}$ ahu, Tottori also prayed for and performed memorial services for individuals not associated with Shingon Buddhism, including Christians and Hongwanji members. As Sadako explains, "In Shingon shū it doesn't matter if they are Christian or other sects, he really respected that and so even in this record that he has, he indicates whether they are Christian or Hongwanji or Sotoshū, Shingon shū." ${ }^{45}$ This sentiment is reaffirmed in research done in 1957 by two local Japanese sociologists studying the cultural traditions of Japanese Americans in Hawai'i. They noted the toleration and blending of different religious traditions in Buddhism that made it difficult for Japanese to accept Christianity exclusively. M. Hilo and Emma K. Himeno argued that the "Japanese see no incongruity" in the "lack of purity or orthodoxy in the Japanese religious outlook," and advised Christian officials to "take account of this background and not be too shocked when they find their religious converts have not altogether cut ties with their former religions." ${ }^{46}$ While Tottori's position as a Buddhist priest may seem incongruous with his prayers for Christian servicemen, the syncretic nature of Buddhism and the "Americanized Buddhism" that existed in the Islands enabled him to pray for Buddhists of all denominations and for Christians.

Tottori's religious flexibility also extended to his children as his 
four sons attended a private Episcopalian school. When son Hiroaki asked his father about the compatibility of sending his children to a Christian school as a Buddhist, he recalled that his father "laughed and said we can accept the Christians, they are all right and that was it. He never went in too much detail as far as why. He thought that any religion was a good religion and it was how you lived your life." ${ }^{47}$ Tottori's religious toleration for other beliefs extended to providing his children with a Christian education. It was also reflected in his desire to ensure the spiritual well-being of Nisei soldiers and he regularly read the newspapers and conducted services for those killed in action. Thus, Tottori also prayed for those he did not know without concern for personal recognition or gain.

There were critics of Tottori's actions as they became well known within the Japanese community. According to Sadako, Tottori's successor, the Reverend Jitsunin Kawanishi, later reported that, "there was a group called kattagumi, pro Japanese and they were really you know, their mindset was that Japan won the war regardless of what the outcome. And that because of my father's belief, they also gave him a bad time. And so it was not only this group of Japanese people there were also a few ministers." 48 Due to Tottori's vocal pro-American stance and the fact that he was an active Japanese Buddhist priest in the Islands, Japanese nationalists who flourished in World War II Hawai'i, due to inconsistent martial law policies and religious freedoms, targeted Tottori.

\section{Seicho no Ie and Kattagumi: "Postwar Delusions" 49}

Despite selective incarceration policies that created anxiety within Hawai'i's Japanese community, there were some who continued, publically, to support Japan and the actions of the Japanese military during the war. As early as 1942 and 1943, various Issei had formed underground kattagumi or kachigumi (victory groups) that disputed American "rumors" of Japanese defeats and strove to keep ethnic pride and confidence alive among Hawai'i's Issei. ${ }^{50}$ In this atmosphere of heightened anxiety and pro-Japanese sentiment among the Issei population, various victory organizations emerged with members from various locations in the Islands. They included Tōbu Dōshi-Kai (東部同志会 “Eastern Association of Kindred Spirits”) in Wai'alae, 
Kōsei-Kai (更生会 “Association for Rehabilitation”) in Pālama, and Hakkō-Kai (八紘会 “Association of Brotherhood”) in Kalihi. ${ }^{51}$ As one member of Tōbu Dōshi-Kai testified, "We are a group of people who retain the Japanese spirit and believe that our fatherland did not lose the war." ${ }^{2}$ The most aggressive group in propagating pro-Japanese notions was Hisshō-Kai (必勝会 “Absolute Victory Group”), which was known as a kattagumi, an organization that believed victory had been achieved.

In spite of these outrageous claims, some Issei did pay membership dues and belonged to Hisshō-Kai. Although exact figures are unavailable, the president of Hisshō-Kai claimed that there were between 3,5 oo and 4 , ooo members in the organization. ${ }^{53}$ Others have provided more conservative figures of 1, ooo total participants, with many holding membership in other organizations. ${ }^{54}$ While formally disbanded only in 1977-thirty-two years after Japan's official surrender-many of Hisshō-Kai's members became discouraged and ended their membership much earlier because of the evident lack of truth in the claims espoused by its leaders, the exposés by former members, and the scathing articles and editorials published by the Hawaii Times. ${ }^{55}$

Ironically, the notion of Japan's "invincibility" was a perception fostered in part by inconsistencies in American war regulations. ${ }^{56}$ At the outbreak of war, authorities restricted all local Japanese radio and newspapers, but permitted direct radio broadcasts from Japan, which were filled with propaganda and news of Japanese victories, until February $1942 .{ }^{57}$ As many alien Japanese could not read or understand English well, they relied on the Japanese media for news of the war, and subsequently many refused to accept the censored news of American war activities when the local Japanese press resumed publication on January 8, 1942. Scholar Andrew Lind noted that during this critical period early in the war, the prohibitions regarding the use of Japanese in radio and print deprived the Issei of "a most effective means of news dissemination and of potential Americanizing influence." ${ }^{58}$ Thus, inconsistency in government policy, as well as the upheaval experienced by the Japanese who were subject to harsh governmental policies and regulations designed to deter their nationalistic activities, inadvertently contributed to the rise of pro-Japanese sentiment.

In lieu of local Japanese newspapers, such as the Hawaii Hochi and 
Nippu Jiji that had been traditional sources of news and events, but which officials had suspended as part of the new war restrictions, some individuals subscribed to mainland Japanese newspapers such as the Colorado Times, Utah Nippo, and Rocky Shimpo. These papers propagated false reports of Japanese victories and celebrated Japan's "invincible tactics" and "fighting spirit." ${ }^{9}$ To certain portions of the population, the existence of these papers, like the radio broadcasts from Tōkyō that were permitted in an environment where officials restricted the local Japanese media and newspapers, seemed to confirm these stories and sanction pro-Japanese sentiment. ${ }^{60}$

Another factor that contributed to nationalistic Japanese attitudes was the rise of a religious sect called Seichō-no-Ie ("House of Growth"), which likewise helped to promote notions of Japan's invincibility and inevitable victory. Despite its obscure origins in Japan, and its small number of converts before the war, this group increased its membership dramatically because it was the only religious group that officials authorized to operate in November 1944, due to its stated objectives of providing memorial services for Japanese American servicemen. ${ }^{61}$ This group attracted a large number of followers given the syncretic nature of Seichō-no Ie, which allowed adherents of different religions to belong to this sect while remaining devoted to their own faiths. The activities of Seichō-no Ie similarly increased in popularity among the anxious parents of Nisei soldiers as the organization's leaders provided prayers, along with claims that they could ensure their safety. According to government statistics, by March 1946 an estimated 4 oo members belonged to the Honolulu branch of Seichō-no Ie, with more than 1,ooo adherents in the Territory; observers noted that number was steadily increasing. ${ }^{62}$

At Seichō-no Ie meetings, which were attended by 200 and $5^{\text {oo }}$ participants, pro-Japanese sentiments were inserted into speeches such as "Demonstrate your Yamato spirit," "We Japanese race," "By the grace of our Emperor," and "Remember our fatherland." 63 Terms and descriptions such as "barbarian" and "inferior" were used to refer to non-Japanese, particularly Americans, and the leaders only acknowledged Japanese American war contributions in describing how many had been saved due to prayers by Seichō-no Ie priests. ${ }^{64}$ Although it is uncertain if audience members embraced these phrases and ideas, it was a radical alternative to the pro-American stance of the sentiments 
of Tottori and the larger mobilization of Hawai'i's Japanese community during war.

\section{Religious and Political Divisions within the Japanese Community on the Issue of Patriotism}

The actions of Seichō-no Ie priests reflected the religious and political divide that existed not just within the remaining religious authorities in Hawai' $i$, but also within the larger Japanese community in the Islands. Seichō-no Ie services began a year after Tottori had started to conduct services for Nisei soldiers. Although the relationship between Seichō-no Ie priests and Tottori is unclear, Seichō-no Ie officials would likely have criticized Tottori's pro-American stance. Within the incarceration centers, a religious and political schism also emerged among the Buddhist priests of the Hongwanji sect. Yasutaro Soga, the Nippu Jiji newspaper editor, reported a disagreement that emerged within the Hongwanji sect on the mainland between two groups-those ministers who sided with the United States and those who supported Japan. Soga highlighted the actions of the Reverend Ryotai Matsukage, who had allegedly issued a statement condemning Japan's attack on Pearl Harbor, and encouraged other ministers to sever relations with the head temple in Japan and support the United States. According to Soga, Matsukage's statements were derided by those who believed that Matsukage and his supporters made these statements to prevent their incarceration. ${ }^{65}$ Although authorities did incarcerate Matsukage, Soga's statements illustrated the political divide that existed within the Japanese community over the issue of loyalty as pro-Japanese groups also flourished in the incarceration centers. Religion became yet another arena for this conflict between ethnicity and loyalty during the war, particularly within the Issei community.

Scholar Duncan Ryūken Williams, who examined the experience of Buddhist priests in incarceration centers, explained that during the war, the very priests who exhibited pro-Japanese tendencies also encouraged the Nisei to volunteer for the 1ooth Infantry Battalion and the 442nd Regimental Combat Team in an apparent contradiction of their beliefs. However, while some Nisei considered volunteering as an expression of their loyalty and "Americanness," for other 
Issei, "the fact that their children were volunteering for U.S. military service was an expression of what they understood to be the traditional Japanese sentiments of a samurai warrior's courage and loyalty in the face of adversity." 66 Subsequently, Issei priests could promote military service for America as a reflection of these Japanese ideals. Tottori himself promoted American military service an important expression of Japanese American identity before, during, and after the conclusion of World War II. Thus, it would be a mistake to understand the experiences and actions of Tottori through the same polarized view of distinct national or cultural identities and allegiances held by the Americans of a Japan-versus-America binary. Priests like Tottori embraced a more fluid notion of identity and saw American military service as an expression of "Japaneseness"; consequently, there was no contradiction between their own loyalty and ties to Japan and the Nisei’s loyalty and military service to America.

\section{TOTTORI's LEGACY}

Even after the war, Tottori continued to conduct services for Nisei veterans of the Korean War, memorializing a total of 420 individuals. In 1946, Tottori became the sixth bishop of the Hawaii Shingon Shū Betsuin and a year later became the director of missionary work in Hawai“i. In 1973, Tottori received the Mikkyo Kyokasho (Shingon Buddhism Missionary Award) in recognition for his dedication to missionary work. When Tottori retired in 1958, he brought the tōba from Hale 'iwa to Liliha Shingonji Mission. Tottori inscribed his hope to end animosity and past conflicts and for friendship and harmony between Japan and the United States on a large o-ihai (wooden tablet) that he dedicated to the Japanese and American soldiers who died during World War II. Tottori prayed over the o-ihai at every spring and autumn Higan (equinox) service and at the annual Obon service where the o-ihai is placed on a special platform, called the O-Segaki Dan ("The Platform for the Hungry Ghosts").

Tottori passed away on January 6, 1976, at the age of 77 following a brief illness. Approximately a thousand mourners attended his funeral services. ${ }^{67}$ Ministers from Koyasan as well as Buddhist ministers of other sects in Hawai'i attended the service with Archbishop Gimo Inaba presiding. Jane Tottori noted that there were 23 


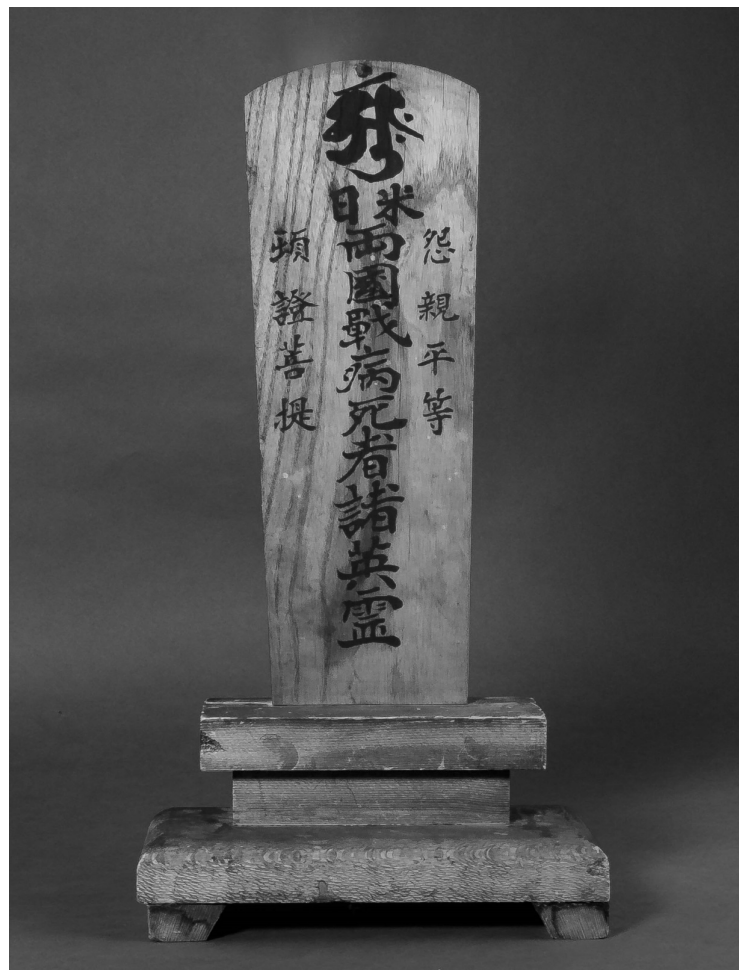

The o-hai (wooden tablet) that Tottori dedicated to the Japanese and American soldiers who died during World War II (front view). 2016. Courtesy of Kelli Y. Nakamura and Shirley S. Lam.

priests in attendance, many of them bishops and other high-ranking individuals that the family had to learn to seat in their proper ranking. "My friend said it was so elegant to see them in their beautiful red robes," she recalled, as these prominent religious officials came to pay their respects from across the island and from Japan in an unprecedented gathering of Buddhist ministers. ${ }^{68}$ Many families for whom he had conducted services as well as friends and relatives of the nine children came to pay their respects. Son Hiroaki recalls his father's service was the largest that he had ever attended, with so 


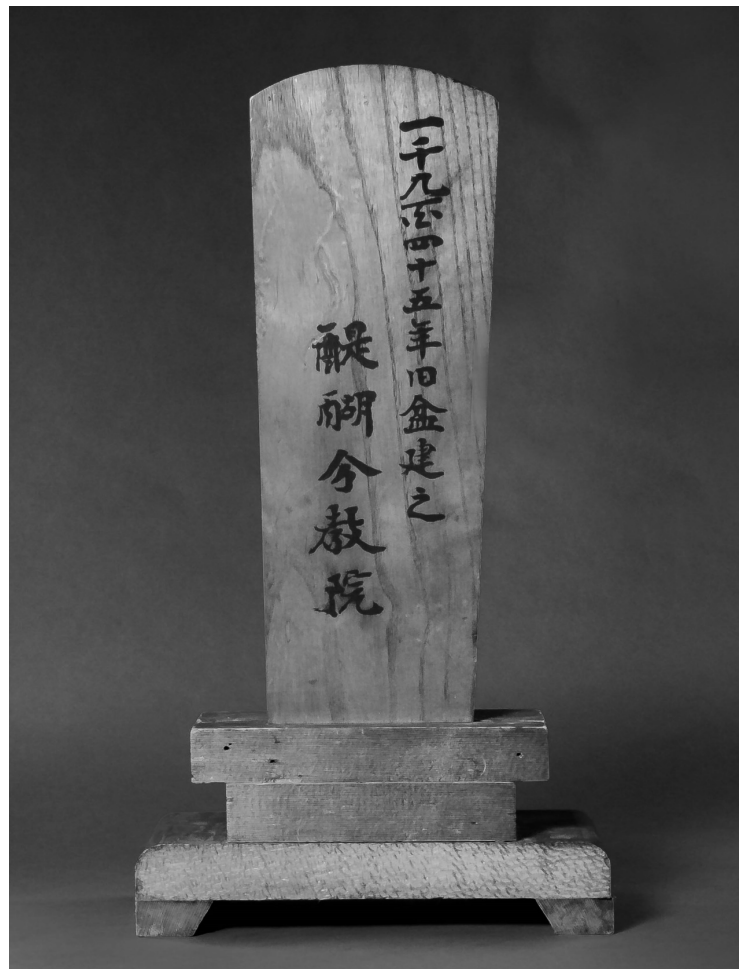

The o-hai (wooden tablet) that Tottori dedicated to the Japanese and American soldiers who died during World War II (back view). 2016. Courtesy of Kelli Y. Nakamura and Shirley S. Lam.

many attendees that Hosoi Garden Mortuary, one of the Honolulu's largest funeral homes, had difficulty accommodating the number of people:

The ministers from the main church, Koyasan, the headquarters for the Shingon sect, they came all the way from Japan, then the other Buddhist ministers and their families, even in Shingon they also have the Hongwanji, and Jōdo, and so forth, they were all there. And then all the families who had got to know my father, and each of the nine children had friends, and they all came. ${ }^{69}$ 


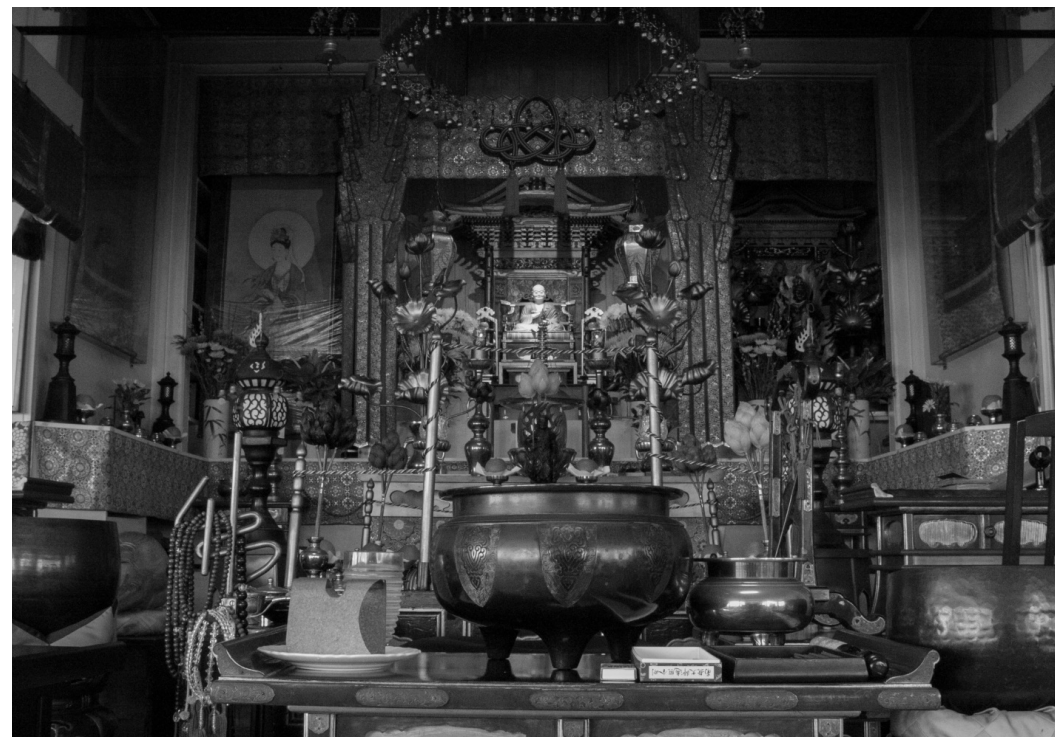

The interior of Liliha Shingonji Mission. 2016. Courtesy of Kelli Y. Nakamura and Shirley S. Lam.

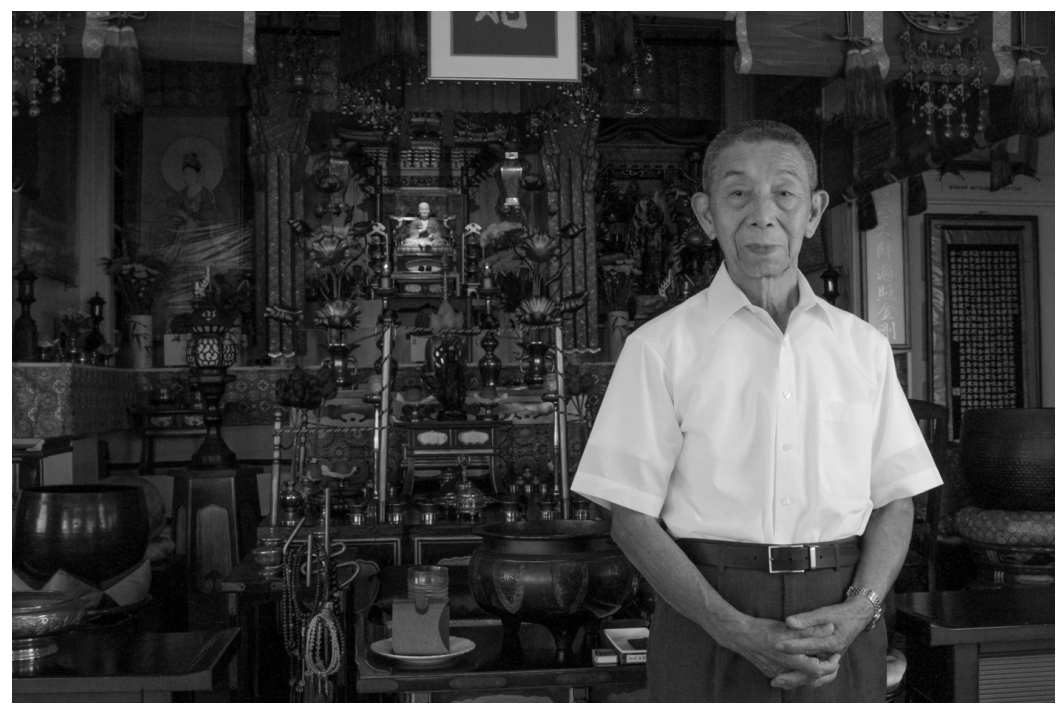

Reverend Jitsunin Kawanishi, translator of the toba and current priest at Liliha Shingonji Mission. 2016. Courtesy of Kelli Y. Nakamura and Shirley S. Lam. 


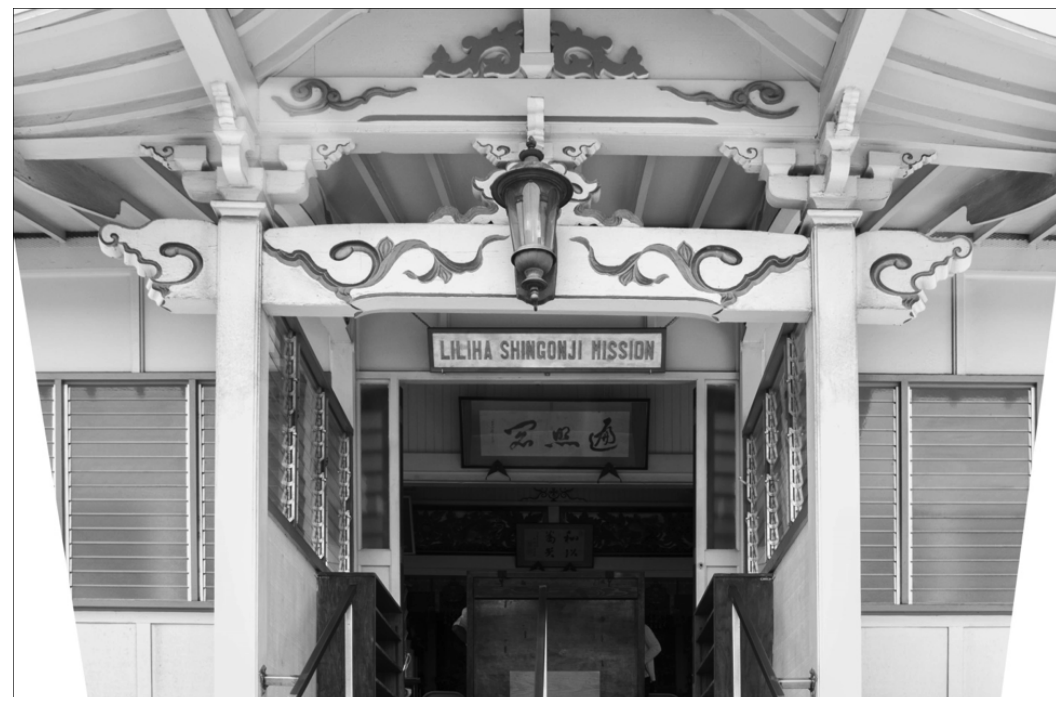

Entrance of Liliha Shingonji Mission. 2016. Courtesy of Kelli Y. Nakamura and Shirley S. Lam.

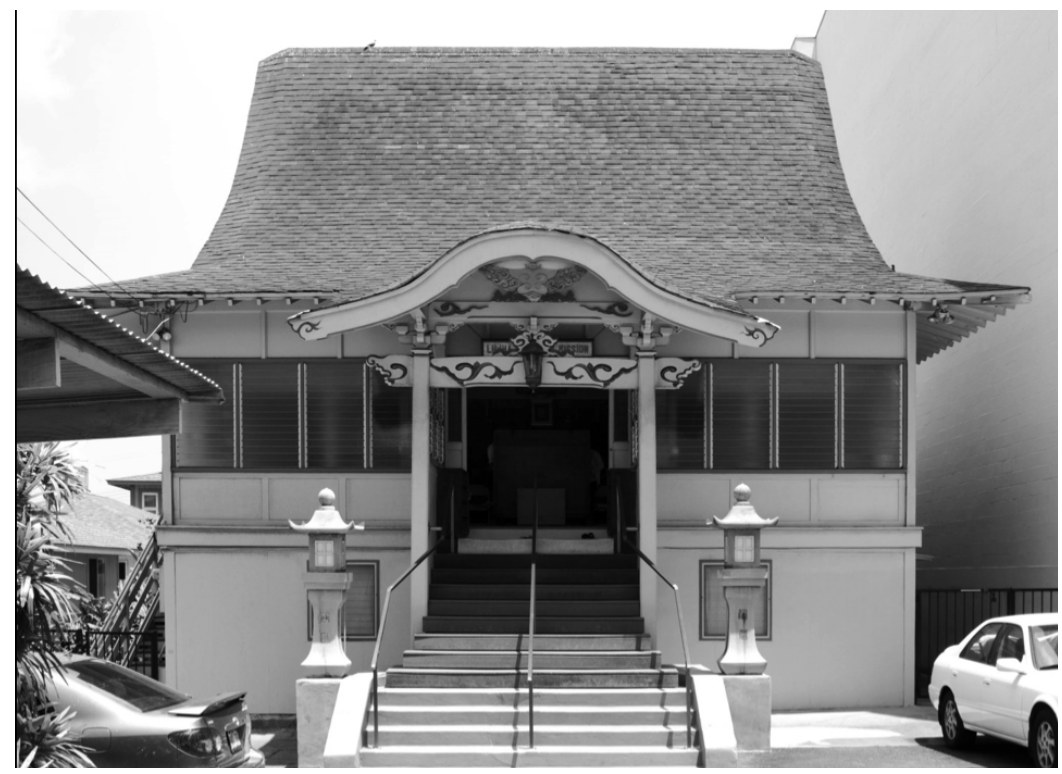

Exterior of Liliha Shingonji Mission. 2016. Courtesy of Kelli Y. Nakamura and Shirley S. Lam. 
Youngest son Kenneth also recalled that "It was just overflowing. They couldn't fit everyone inside. It was even outside and all." ${ }^{70}$ Although no mention was made of Tottori's activities during the war, the number and diversity of the attendees, who included leaders of other Buddhist sects, testifies to the collective impact of his life and his actions. Even after the war, Tottori did not share much about his wartime activities with his own children, who went on to live successful lives relatively untouched by the impact of war. Tottori's own FBI file does not acknowledge any wartime activities beyond his interview with FBI officials at the start of the war; the additional documents in his file relate to his naturalization to become an American citizen in 1959 . Even after his retirement and passing, his successor, Reverend Jitsunin Kawanishi, continues Tottori's remembrance of Hawai'i's Nisei, praying over the o-ihai at these services. Thus, the memorialization of the Nisei that began in 1943 still continues more than 70 years later at the Liliha Shingonji Mission.

\section{Conclusion}

While considerable scholarship has been done on the dual identities of the Nisei during the war, it has often been assumed that the Issei identified with Japan and passively, or in some cases actively, sided with Japan as authorities denied them American citizenship and rights, and arrested and incarcerated those they deemed suspect. The activities of Tottori, however, illustrate the complexity of Issei loyalties and identity as Tottori promoted the loyalty of the Nisei to America through Buddhism and saw Japanese values as compatible with Americanization. Although it still remains unclear why authorities did not arrest and incarcerate Tottori, his actions during and after the war testify to an Americanized Buddhism that utilized Japanese values and ideas to promote America's victory during World War II.

Two striking facts surround understanding the World War II experiences of Tottori. First, authorities allowed Tottori to remain free, despite incarcerating other priests who shared his views of encouraging Japanese loyalty to America. Second, Tottori continued to conduct religious services which became widely known in the Japanese community—not just on O'ahu but on the other Hawaiian Islands. Plantation managers facilitated Tottori's actions by providing extra 
gas rations to enable Tottori to conduct services in various communities. Additionally, although Tottori was prohibited from traveling to the other islands under martial law restrictions, this failed to deter Japanese from other islands from contacting Tottori, potentially putting them at risk for communicating with him, to hold memorial services.

As Tottori promoted the loyalty of the Nisei to America, he experienced opposition from Japanese nationalists, many of whom were associated with Seichō no Ie, the only remaining Japanese religious organization that authorities also allowed to exist. Although Tottori and Seichō no Ie members took opposing positions on the issue of Japanese loyalty, the fact that authorities allowed these and other religious exceptions to remain in Hawai'i reveals a striking, yet unexplained inconsistency in martial law policies. Thus, the experiences of Tottori reflect the challenges of uniformly characterizing the experiences of Japanese in Hawai'i during World War II, and the loyalty of the Issei generation with the unprecedented and sometimes inconsistently applied extension of martial law.

\section{Acknowledgements}

I would like to express my deep appreciation and gratitude to Jane Kurahara of the Japanese Cultural Center of Hawai'i who brought this story to my attention. I also want to thank the Tottori family who generously shared information about their father and the Reverend Jitsunin Kawanishi who assisted me throughout this project.

\section{Notes}

${ }^{1}$ Duncan R. Williams, "Complex Loyalties: Issei Buddhist Ministers during the Wartime Incarceration," Pacific World, 3rd ser., no. 5 (Fall 2003): 263.

${ }^{2}$ His colleague, Reverend Shindo Wasai was also not incarcerated but very little information is currently known about him or his World War II experiences. Reverend Yoshiko Shimabukuro who was the priest of the Jōdo Shinshū at the 'Ele'ele Honwanji on Kaua'i was also not incarcerated, although FBI officials did fingerprint, photograph, and question her at Kaua'i County Building. As the only Buddhist priest on Kaua'i, she conducted funeral, memorial, and Obon services along with weddings during the war and believes that she was not incarcerated as "maybe they felt sorry for me because I was handicapped. 
But I don't know." As a breach baby, she lost her left arm at birth but that did not prevent her from becoming the first Nisei Okinawan woman to serve as a Jōdo Shinshū minister in Hawai'i. Tetsuei Katoda, The Fiftieth Anniversary of the Establishment of the Shingon Sect Mission of Hawaii (Honolulu: the Mission, 1966) 58; Roy M. Kodani, "Yoshiko Shimabukuro," Hawaii Herald, 4 July 2003, A-1o.

3 "Shall Hawaii Be American or Alien?" PCA, 27 January 1920, 4.

${ }^{4}$ Tetsuei Katoda, The Fiftieth Anniversary of the Establishment of the Shingon Sect Mission of Hawaii (Honolulu: Honolulu the Mission, 1966) 4-5.

${ }^{5}$ Dennis Ogawa, Kodomo No Tame Ni: For the Sake of the Children (Honolulu: University of Hawaii Press, 1978) $5^{1 .}$

${ }^{6}$ George J. Tanabe and Willa Jane Tanabe, Japanese Buddhist Temples in Hawaii: An Illustrated Guide (Honolulu: University of Hawai'i Press, 2013) 7.

${ }^{7}$ Williams, "Complex Loyalties" 261.

${ }^{8}$ National Archives at San Francisco. USIS (RG 566) series: Alien Case Files, File: Mitsumyo Tottori: \#A2071 200 in Box 110.

${ }^{9}$ Noriko Asato, Teaching Mikadoism: The Attack on Japanese Language Schools in Hawaii, California, and Washington, I919-1927 (Honolulu: University of Hawaii Press, 2006) 23.

${ }^{10}$ Isao Horinouchi, "Americanized Buddhism: A Sociological Analysis of a Protestantized Japanese Religion,” (Ph.D. Diss., University of California Davis, 1973) 100.

${ }^{11}$ Vaughan MacCaughey, "Some Outstanding Educational Problems of Hawaii," School and Society 9 (January 1919): 100-101.

${ }^{12}$ U.S. Department of the Interior Bureau of Education, A Survey of Education in Hawaii, no. 16, 1920, 134 .

13 "Hand Across the Sea," PCA, zo January 1920, 4.

14 "What the Japanese Agitators Want," HSB, 13 February 1920, 6.

15 "Shall Hawaii Be American or Alien?" PCA, 27 January 1920, 4.

${ }^{16}$ H.S Burr, U.S. Navy Reserve, District Intelligence Officer, U.S. Navy, "Naval Intelligence Manual for Investigating Japanese Cases in Hawaii," RG 389: Record of the Office of the Provost Marshal General, 1941-, Japanese Internment and Relocation: Hawaii Experience [henceforce JIRHE], University of Hawai'i, Hamilton Library, Special Collections, box 3, A-4o, pp. $5^{\mathrm{O}-5^{1}}$.

${ }^{17}$ H.S. Burr, $5^{\mathrm{O}-5^{1}}$.

18 “Mr. Myoshu Sasai," JIRHE Item 239, 2.

9 "Mr. Myoshu Sasai" 1.

20 "Mr. Myoshu Sasai" 2.

"Mr. Myoshu Sasai" 3.

${ }^{22}$ Yasutaro Soga, Life Behind Barbed Wire: The World War II Internment Memoirs of a Hawai'i Issei (Honolulu: University of Hawai'i Press, 2008) 91.

${ }^{23}$ Yoshihide Matsubayashi, "The Japanese Language Schools in Hawaii and California From 1892 to 1941," (Ed. D diss, University of San Francisco, 1984) 235.

${ }^{24}$ Yemyo Imamura, Democracy According to the Buddhist Viewpoint (Honolulu: The Publishing Bureau of the Hongwanji Mission, 1918) 8. 
${ }^{25}$ Imamura, Democracy According to the Buddhist Viewpoint 5 .

${ }^{26}$ Michihiro Ama, Immigrants to the Pure Land: The Modernization, Acculturation, and Globalization of Shin Buddhism, I 898-I94I (Honolulu: University of Hawai' $\mathrm{i}$ Press, 2011$) 182$.

27 Williams, "Complex Loyalties" $255^{-274}$.

${ }^{28}$ National Archives at San Francisco. USIS (RG 566) series: Alien Case Files, File: Mitsumyo Tottori \#A2071200 in Box 110.

${ }^{29}$ Kazuko Makishima, interview with Kelli Y. Nakamura, August 3, 2015.

${ }^{30}$ Lawrence H. Fuchs, Hawaii Pono: A Social History (New York: Harcourt, Brace \& World, Inc., 1961) 129; Mark K. Santoki, "Iwao Mizuta: Reflection on the McKinley Class of ' 34 and the Legacy of Miles Cary," Hawaii Herald, 1 November 1991, 1

${ }^{31}$ Lon Kurashige, "The Problem of Biculturalism: Japanese American Identity and Festival Before World War II," The Journal of American History 86: 4 (March 2000): 1632-1654.

32 Sumiko Mashiyama, interview with Kelli Y. Nakamura, August 3, 2015.

33 Sadako Kaneko, interview with Kelli Y. Nakamura, August 3, 2015.

${ }^{34}$ Sumiko Mashiyama, interview with Kelli Y. Nakamura, August 3, 2015.

${ }^{35}$ Kōyasan Shingonshū Kaikyōkyoku, History of Shingon Buddhism in Hawaii (Wakayama-ken Ito-gun Kōya-chō: Kōyasan Shingonshū Kaikyōkyoku, 2oo6) 59.

${ }^{36}$ Sadako Kaneko, interview with Kelli Y. Nakamura, August 3, 2015.

37 Jane Tottori, interview with Kelli Y. Nakamura, August 3, 2015.

${ }^{38}$ Sadako Kaneko, interview with Kelli Y. Nakamura, August 3, 2015.

${ }^{39}$ Kazuko Makishima, interview with Kelli Y. Nakamura, August 3, 2015.

${ }^{40}$ Gwenfread Allen, Hawaii's War Years (Westport, Connecticut: Greenwood Press, 1971) $35^{1}$.

${ }^{41}$ Allen, Hawaii's War Years 264.

${ }^{42}$ Kazuko Makishima, interview with Kelli Y. Nakamura, August 3, 2015.

${ }^{43}$ United States. Bureau of the Census. Sixteenth Census of the United States: 1940: Territories and Possessions (New York, N.Y.: Ross Publishing Inc., 2005) 32.

${ }^{44}$ Honolulu Japanese Chamber of Commerce. “虹の橋”: 日工商 70 年史 = “The Rainbow": A History of the Honolulu Japanese Chamber of Commerce (Honolulu: Nihonjin Shōkō Kaigisho; Honolulu, 1970) 178.

${ }^{45}$ Sadako Kaneko, interview with Kelli Y. Nakamura, August 3, 2015.

${ }^{46}$ M. Hilo and Emma K. Himeno, "Some Characteristics of American and Japanese Culture," Social Process in Hawaii 21 (1957): 41.

${ }^{47}$ Hiroaki Tottori, interview with Kelli Y. Nakamura, October 23, 2015.

${ }^{48}$ Sadako Kaneko, interview with Kelli Y. Nakamura, August 3, 2015. For an account of Tottori's actions during World War II by Kawanishi see: 実仁川西 [Jitsunin Kawanishi], “胸 が晴れる一戦時下のハワイ時報 [Mune ga hareru一 sennjishita no hawai jihō,” 高野山時報 [Koyasan Jihō] (2016): 59-61.

49 "Some Older Japanese Here Said Gripped By 'Psychic Epidemic,” HA, 4 March 1946, 1; "Postwar Delusions of Old Japanese Here Studied By UH Research Unit," HSB, 9 March 1946, 16. 
${ }^{50}$ John J. Stephan, Hawaii Under the Rising Sun: Japan's Plans for Conquest After Pearl Harbor (Honolulu: University of Hawaii Press, 1984) 172.

51 The Romanzo Adams Social Research Laboratory (RASRL), A-1 989: oo6, Box 10-1 1, "Mr. Y., Waialae Ave., April 1 1, 1947," 3. According to a member of Tōbu Dōshi-Kai, his organization had about 3 oo members while Kōsei-Kai had about 200 and Hakkō-Kai 100 members. The translation for Hakkō-Kai could possibly have a more nationalistic orientation. According to one scholar, the word 八紘 (Hakkō) comes from the saying 八紘一宇 (Hakkō-ichiu), which has two meanings: "universal brotherhood" or "all eight corners of the world under one roof," meaning under the control of Japan. Yukiko Kimura, "A Sociological Analysis of Types of Social Readjustment of Alien Japanese in Hawaii Since the War" (master's thesis, University of Hawaii at Manoa, 1947) 136.

52 The Romanzo Adams Social Research Laboratory (RASRL), A-1989: oo6, Box 10-1 1, "Mr. Y., Waialae Ave., April 11, 1947," 1.

53 The Romanzo Adams Social Research Laboratory (RASRL), A-1 989: oo6, Box 10-11, "MEMBERSHIP FEE OF HISSHO-KAI IS \$10.0o-4,ooo PAID-UP MEMBERS," 26 July 1948.

${ }^{54}$ Kimura, 126.

${ }^{55}$ On November 17, 1977, Hisshō-Kai secretary Seiichi Masuda announced the formal disbanding of the organization in an announcement published in the Hawaii Hochi. “八ワイ島必勝会解解の辞, ” Hawaii Hochi, 17 November 1977, 4 .

${ }^{56}$ Kimura, 29.

57 Andrew W. Lind, The Japanese in Hawaii Under Wartime Conditions (Honolulu, New York: American Council, Institute of Pacific Relations, 1943) 19.

58 Lind, The Japanese in Hawaii 21.

59 The editor of the Colorado Times estimated that there were approximately 1,000 subscribers in Hawai'i. However, the total readership is estimated to be much larger as "the same copy was passed around among a number of friends and relatives." One scholar notes that "the number of readers was several times larger than the number of subscribers and consequently the effects of those papers were "far reaching." Kimura, 51, 202, 207.

${ }^{60}$ Kimura, 59 .

${ }^{61}$ Kimura, 65. Masaharu Taniguchi founded Seichō-No Ie in 1930 as a nondenominational movement based on the belief that all religions emanate from one universal God. It was introduced to Hawai'i around 1935, and its adherents disseminated its holy scripture, Seimei-no Jisso (The Reality of Life) and its monthly publication called Seichō-no Ie. Kimura, "A Sociological Analysis" 62-64; What People In Hawaii are Saying and Doing, War Research Laboratory, University of Hawaii, March I, I946 Report No. 8. [Honolulu]: n.p. 1952.

${ }^{62}$ Kimura, 69.

${ }^{63}$ Kimura, 66; Yukiko Kimura, "A Comparative Study of the Collective Adjustment of the Issei, the First Generation Japanese, in Hawaii and the Mainland United States Since Pearl Harbor" (Ph.D. diss., University of Chicago 1952), $35^{6}$.

${ }^{64}$ Kimura, "A Comparative Study," 356-357. 
${ }^{65}$ Soga, 92.

${ }_{66}^{6}$ Williams, "Complex Loyalties" 270.

67 "Tottori, Bishop Mitsumyo," HA, 1 o January 1967, C-7.

${ }^{68}$ Jane Tottori, interview with Kelli Y. Nakamura, March 30, 2016.

${ }^{69}$ Hiroaki Tottori, interview with Kelli Y. Nakamura, October 23, 2015.

${ }^{70}$ Kenneth Tottori, interview with Kelli Y. Nakamura, October 23, 2015. 
